\title{
ANALISIS KINERJA APARATUR SIPIL NEGARA DI BADAN SIBER DAN SANDI NEGARA TAHUN 2019
}

\author{
I Made Adnyana ${ }^{1 *}$, Asadini Dwi Ajeng Gemellia ${ }^{1}$ \\ ${ }^{1}$ Program Studi Manajemen, Universitas Nasional \\ Email: madeadnyana572@gmail.com, asadini.gemellia@gmail.com. \\ *Korespondensi: madeadnyana572@gmail.com \\ (Submission 07-09-2021, Revissions 22-09-2021, Accepted 23-09-2021).
}

\begin{abstract}
This research aims to see the effect of Work Flexibility, Work-Life Balance, Reward and Non-Physical Work Environment on Employee Performance at BSSN using Structural Equation Model (SEM) analysis through AMOS 24 software. The results show that the variables of Work Flexibility, Work Life Balance, Reward and Non-Physical Work Environment respectively have a positive and significant effect on BSSN Employee Performance. The reward variable has the strongest effect and the Non-Physical Work Environment variable has the smallest effect on BSSN Employee Performance, so that the policy that can be applied by the OSDM Bureau is to implement PP 30 of 2019 by providing promotions and prioritizing employee development for employees who have excellent $P 2 K P$ results for 2 consecutive years and good for 2 consecutive years.
\end{abstract}

Keywords: employee performance, work flexibility, work life balance, reward, non physical work environment.

\begin{abstract}
Abstrak
Penelitian ini bertujuan untuk melihat pengaruh fleksibilitas kerja, keseimbangan kehidupan kerja, penghargaan dan lingkungan kerja non fisik terhadap kinerja pegawai BSSN dengan menggunakan analisis Structural Equation Model (SEM) melalui software AMOS 24. Hasil penelitian menunjukkan bahwa variabel fleksibilitas kerja, keseimbangan kehidupan kerja, penghargaan dan lingkungan kerja non fisik masing-masing berpengaruh positif dan signifikan terhadap kinerja pegawai BSSN. Variabel penghargaan memberikan pengaruh terkuat dan variabel lingkungan kerja non fisik memberikan pengaruh terkecil terhadap kinerja pegawai BSSN, sehingga kebijakan yang dapat diterapkan oleh Biro OSDM adalah menerapkan PP 30 Tahun 2019 dengan pemberian promosi dan prioritas pengembangan pegawai bagi pegawai yang memiliki hasil P2KP sangat baik selama 2 tahun berturut-turut dan baik selama 2 tahun berturut-turut.
\end{abstract}

Kata Kunci: kinerja pegawai, fleksibilitas kerja, keseimbangan kehidupan kerja, penghargaan, lingkungan kerja non fisik. 


\section{PENDAHULUAN}

Sumber Daya Manusia (SDM) merupakan komponen utama dan terpenting serta memberikan pengaruh yang besar bagi perkembangan suatu organisasi, karena mereka menjadi perencana dan pelaku aktif dalam setiap aktivitas organisasi. Sumber daya manusia pada sektor pemerintahan disebut Aparatur Sipil Negara (ASN) yang terdiri dari Pegawai Negeri Sipil (PNS) dan Pegawai Pemerintah dengan Perjanjian Kerja (PPPK). Saat ini telah terjadi perubahan paradigma dalam pengelolaan pegawai ASN. Jika perspektif lama memandang pegawai hanya sebagai faktor produksi, maka dengan pendekatan human capital yang saat ini dianut, pegawai dipandang sebagai aset organisasi. Pembangunan SDM Unggul termasuk bagian dalam mewujudkan ASN yang memiliki kompetensi tinggi, mencapai kinerja terbaik serta berintegritas untuk mendukung birokrasi yang bersih dan melayani.

Globalisasi menjadi salah satu tantangan pada organisasi. Indonesia memasuki era industri 4.0 melalui ditetapkannya roadmap "Making Indonesia 4.0" dengan inisiatif lintas sektor, yaitu pembangunan infrastruktur digital nasional. Ini berarti Indonesia harus siap dengan era transformasi digital dimana keamanan siber menjadi bagian terpenting dalam era revolusi Industri 4.0 terutama melawan ancaman kejahatan siber yang semakin beragam dan berdampak masif secara nasional serta mengancam kedaulatan bangsa. Lembaga Sandi Negara pun bertransformasi menjadi Badan Siber dan Sandi Negara (BSSN).

The International Telecommunication Union (ITU), organisasi internasional penyelenggara Pemeringkatan Indeks Keamanan Siber Global, pada bulan Juli 2019 mempublikasikan laporan resmi hasil GCI tahun 2018. Hasil pencapaian Indonesia berada di peringkat 41 dari 175 negara pada tahun 2018. Peringkat ini menunjukkan bahwa menjaga stabilitas keamanan nasional khususnya di bidang siber sangat diperlukan untuk meningkatkan nilai Indonesia pada GCI. Dalam perspektif sumber daya manusia, peringkat ini juga menunjukkan bahwa BSSN dituntut untuk mengelola SDM yang dimilikinya agar mampu mendukung pencapaian tujuan organisasi.

Indeks Profesionalitas Aparatur Sipil Negara (IP ASN) merupakan ukuran statistik yang menggambarkan kualitas ASN berdasarkan kesesuaian kualifikasi, kompetensi, kinerja dan kedisiplinan pegawai ASN dalam melaksanakan tugas jabatan. IP ASN menjadi indikator kinerja yang digunakan Sekretariat Utama di lingkungan Badan Siber dan Sandi Negara. Hasil pengukuran IP ASN di BSSN pada tahun 2018 dan tahun 2019 bisa dilihat pada Tabel 1.

Tabel 1 menunjukkan nilai IP ASN di BSSN pada tahun 2018 dan 2019 berada dalam rentang nilai 81 - 90, sehingga termasuk dalam kategori Tinggi yang artinya cenderung profesional. Namun terdapat penurunan nilai yang signifikan antara nilai IP ASN tahun 2018 dengan nilai IP ASN tahun 2019 sebesar 3,15 poin, dimana penurunan terbesar terdapat pada dimensi kinerja sebesar 1,21 poin. Dimensi kinerja ini dihitung berdasarkan rata-rata hasil Penilaian Prestasi Kerja Pegawai (P2KP). Hal ini mengindikasikan kurang optimalnya pengelolaan kinerja pegawai di BSSN. Indikasi ini juga bisa dilihat melalui data kehadiran pegawai BSSN periode Januari hingga Desember tahun 2019 pada Tabel 2. 
Tabel 1. Data Hasil Pengukuran IP ASN di BSSN Tahun 2018 dan 2019

\begin{tabular}{|c|l|l|l|l|l|}
\hline \multirow{2}{*}{ No } & \multicolumn{1}{|c|}{ IP ASN } & \multicolumn{1}{|c|}{ Dimensi } & $\begin{array}{c}\text { Bobot } \\
\text { Dimensi }\end{array}$ & $\begin{array}{c}\text { Hasil } \\
\text { Pengukuran }\end{array}$ & $\begin{array}{c}\text { Total Hasil } \\
\text { IP ASN }\end{array}$ \\
\hline \multirow{2}{*}{1} & \multirow{2}{*}{\begin{tabular}{l} 
IP ASN Tahun \\
\multirow{2}{*}{2018}
\end{tabular}} & Kualifikasi & $25 \%$ & 14,74 & \multirow{2}{*}{86,18} \\
\cline { 3 - 5 } & Kompetensi & $40 \%$ & 39,02 & \\
\cline { 3 - 5 } & & Kinerja & $30 \%$ & 27,43 & \\
\cline { 3 - 5 } 2 & Disiplin & $5 \%$ & 4,99 & \multirow{3}{*}{83,03} \\
& \multirow{2}{*}{2019} & Kualifikasi & $25 \%$ & 13,37 & \\
\cline { 3 - 5 } & & Kompetensi & $40 \%$ & 38,44 & \\
\cline { 3 - 5 } & Kinerja & $30 \%$ & 26,22 & \\
\cline { 3 - 4 } & Disiplin & $5 \%$ & 4,99 & \\
\hline
\end{tabular}

Sumber: Diolah dari dokumentasi Subbagian Pengelolaan Kinerja Pegawai BSSN

Tabel 2. Data Absensi pegawai BSSN periode Januari - Desember 2019

\begin{tabular}{|l|l|l|l|l|l|}
\hline \multirow{2}{*}{ Bulan } & \multirow{2}{*}{ Total Pegawai } & \multicolumn{2}{|l|}{ Tidak Masuk } & \multicolumn{2}{l|}{ Terlambat } \\
\cline { 3 - 6 } & & Jumlah & $\mathbf{\%}$ & Jumlah & \% \\
\hline Januari & 968 & 370 & 38,2 & 392 & 40,5 \\
\hline Februari & 1099 & 311 & 28,3 & 917 & 83,4 \\
\hline Maret & 1099 & 340 & 30,9 & 879 & 80,0 \\
\hline April & 1099 & 270 & 24,6 & 753 & 68,5 \\
\hline Mei & 1099 & 272 & 24,7 & 703 & 64,0 \\
\hline Juni & 1099 & 226 & 20,6 & 371 & 33,8 \\
\hline Juli & 1099 & 299 & 27,2 & 750 & 68,2 \\
\hline Agustus & 1099 & 361 & 32,8 & 685 & 62,3 \\
\hline September & 1099 & 267 & 24,3 & 565 & 51,4 \\
\hline Oktober & 1099 & 259 & 23,6 & 551 & 50,1 \\
\hline November & 1099 & 255 & 23,2 & 514 & 46,8 \\
\hline Desember & 1099 & 20 & 1,8 & 551 & 50,1 \\
\hline Rata-rata & $\mathbf{1 0 8 8}$ & $\mathbf{2 7 1}$ & $\mathbf{2 5 , 0}$ & $\mathbf{6 3 6}$ & $\mathbf{5 8 , 3}$ \\
\hline
\end{tabular}

Sumber: Diolah dari dokumentasi Subbagian Data dan Informasi BSSN 2019

Tabel 2 memperlihatkan periode Januari hingga Desember 2019, jumlah pegawai yang tidak masuk dan terlambat cukup tinggi dengan rata-rata 271 dan 636 pegawai yang tidak masuk dihitung berdasarkan ijin, sakit dan tidak masuk tanpa keterangan per bulan. Sehingga persentase pegawai tidak masuk dan terlambat sebesar $25 \%$ dan $58,3 \%$. Hal ini mengindikasikan bahwa sebagian pegawai BSSN belum mentaati peraturan organisasi khususnya aturan mengenai absensi pegawai.

Bangun (2012) menyatakan bahwa kinerja karyawan adalah hasil pekerjaan yang dicapai seseorang berdasarkan persyaratan-persyaratan pekerjaan, dimana 
kinerja dapat dinilai atau diukur dengan beberapa indikator. Suatu pekerjaan dapat diukur melalui jumlah, kualitas, ketepatan waktu, kehadiran, dan kemampuan bekerjasama. Data kinerja pegawai BSSN tahun 2018 dan 2019 menunjukkan perlunya peningkatan. Kinerja pegawai dipengaruhi oleh banyak faktor. Salah satunya adalah fleksibilitas jam kerja. Fleksibilitas jam kerja memiliki pengaruh positif dan signifikan terhadap kinerja karyawan (Fanda \& Slamet, 2019). Pada tahun 2019, BSSN mulai menggunakan Flexitime dengan toleransi keterlambatan sebanyak 15 menit. Pada awal tahun 2020 ketika terjadi pandemi Covid 19 di Indonesia, ASN di BSSN mulai melaksanakan Work From Home (WFH) untuk mendukung kinerja pegawai di BSSN. WFH ini termasuk fleksibilitas jam kerja yang diberikan oleh BSSN.

Faktor lain yang mempengaruhi kinerja pegawai adalah keseimbangan kehidupan kerja atau Worklife Balance (Saina et al., 2016). Terhadap faktor ini, BSSN mendukung dengan pengadaan ruang laktasi dan pulang mendahului selama 3 bulan setelah cuti melahirkan untuk ibu menyusui, pengadaan jemputan untuk mendukung transportasi pegawai BSSN, adanya cuti pegawai yang dapat digunakan oleh pegawai sewaktu-waktu jika dibutuhkan, dan adanya rusunawa untuk tempat tinggal pegawai pada segmen tertentu, serta terdapat ruang karaoke dan alat gym untuk mendukung hiburan dan kesehatan pegawai.

Faktor yang juga mempengaruhi adalah penghargaan. Penghargaan berpengaruh positif signifikan terhadap kinerja karyawan (Prabu \& Wijayanti, 2016). Berdasarkan Perka Lembaga Sandi Negara Nomor 1 Tahun 2016 pasal 1 ayat (4), dinyatakan bahwa bentuk reward atau penghargaan kepada pegawai didasarkan pada capaian kinerja pegawai yang sejalan dengan capaian kinerja organisasi dimana pegawai tersebut berada, yaitu berupa tunjangan kinerja. Selain itu, penghargaan lainnya juga diterima pegawai karena kesetiaan dan masa kerja pegawai berupa Tanda Kehormatan Satyalancana Karya Satya dari Presiden Republik Indonesia dan Tanda Penghargaan Dharma Persandian dari Kepala Badan Siber dan Sandi Negara. Faktor berikutnya adalah lingkungan kerja non fisik. Menurut Noerlestari dan Silvianita (2013), lingkungan kerja non fisik berpengaruh pada kinerja karyawan. Lingkungan kerja non fisik adalah keadaan yang berkaitan dengan hubungan kerja di dalam organisasi tersebut. Berdasarkan uraian di atas, penelitian ini dilakukan untuk mengetahui: Apa pengaruh fleksibilitas kerja, keseimbangan kehidupan kerja, penghargaan dan lingkungan kerja non fisik terhadap kinerja pegawai di lingkungan Badan Siber dan Sandi Negara?

\section{Konsep dan Definisi}

- Manajemen Sumber Daya Aparatur Sipil Negara

Manajemen sumber daya Aparatur Sipil Negara sejatinya tidak berbeda dengan manajemen sumber daya manusia, sehingga pengertiannya pun tidak bertolak belakang satu sama lain. Manajemen sumber daya aparatur banyak diartikan sebagai suatu pengelolaan, pendayagunaan, pengkoordinasian, pengaturan, pengembangan, penilaian kinerja, pemberian balas jasa (kompensasi) dan pengawasan terhadap segala bentuk aktivitas yang dilakukan oleh lembaga pemerintah terhadap semua unsur pegawai sebagai individu anggota organisasi 
pemerintahan yang terlibat dan semua potensinya. Aparatur, menurut Dharma Setyawan Salam (2004), diartikan sebagai pegawai yang digaji langsung oleh Pemerintah yang melaksanakan tugas-tugas teknis pemerintahan dalam melakukan pelayanan langsung kepada masyarakat berdasarkan peraturan dan perundangundangan yang berlaku.

\section{- Kinerja Pegawai}

Kinerja atau prestasi kerja merupakan hasil yang dicapai seseorang menurut ukuran yang berlaku, dalam kurun waktu tertentu, berkenaan dengan pekerjaan serta perilaku dan tindakannya (Suwatno, 2011). Pengukuran kinerja, menurut Bangun (2012) adalah suatu pekerjaan dapat diukur melalui jumlah, kualitas, ketepatan waktu mengerjakannya, kehadiran dan kemampuan bekerja sama yang dituntut suatu pekerjaan tertentu. Penilaian kinerja pegawai mengacu pada suatu sistem formal yang memiliki dasar yang disepakati untuk mengukur, menilai, dan mempengaruhi sifat-sifat pekerjaan yang berkaitan dengan perilaku dan hasil pekerjaan tersebut, termasuk dalam hal kedisiplinan pegawai (Rivai, 2013).

\section{- Penilaian Kinerja}

Kinerja ASN diatur dalam Peraturan Pemerintah (PP) nomor 30 tahun 2019 tentang Penilaian Kinerja Pegawai Negeri Sipil (PNS) dimana PP tersebut merupakan perbaikan dari PP yang telah ada sebelumnya, yakni PP nomor 46 tahun 2011 tentang Penilaian Prestasi kerja PNS. Di dalam PP tersebut disebutkan bahwa penilaian prestasi kerja PNS merupakan suatu proses penilaian secara sistematis yang dilakukan oleh pejabat penilai terhadap sasaran kerja pegawai dan perilaku PNS.

\section{- Indikator Kinerja}

Indikator kinerja merupakan ukuran secara kuantitatif maupun secara kualitatif untuk secara langsung mendeskripsikan tingkat pencapaian tujuan dan sasaran organisasi. Indikator kinerja juga dapat digunakan untuk menjadi tolok ukur kemajuan yang sudah diraih oleh seorang pegawai, apakah pencapaian kinerja tahun ini lebih baik dari tahun-tahun sebelumnya atau tidak. Hal tersebut bertujuan untuk pengukuran pencapaian sasaran dan tujuan organisasi. Indikator kinerja menurut Peraturan Pemerintah Nomor 46 Tahun 2011 tentang Penilaian Prestasi Kerja Pegawai Negeri Sipil yaitu sasaran kinerja pegawai (SKP) dan perilaku kerja. SKP meliputi kuantitas, kualitas, waktu dan biaya, sedangkan perilaku kerja terdiri atas orientasi pelayanan, integritas, komitmen, disiplin, kerja sama, dan kepemimpinan. Bangun (2012) menyebutkan bahwa suatu pekerjaan dapat diukur melalui jumlah, kualitas, ketepatan waktu mengerjakannya, kehadiran dan kemampuan bekerja sama yang dituntut suatu pekerjaan tertentu. Penjelasan ini diuraikan sebagai berikut:

1) Jumlah pekerjaan, yaitu jumlah pekerjaan yang dihasilkan individu atau kelompok sebagai persyaratan yang menjadi standar pekerjaan. Setiap pekerjaan memiliki persyaratan yang berbeda sehingga menuntut karyawan harus memenuhi persyaratan tersebut baik pengetahuan, keterampilan, maupun kemampuan yang sesuai. Berdasarkan persyaratan pekerjaan 
tersebut dapat diketahui jumlah karyawan yang dibutuhkan untuk dapat mengerjakannya, atau setiap karyawan dapat mengerjakan berapa unit pekerjaan.

2) Kualitas pekerjaan, yaitu setiap karyawan dalam perusahaan harus memenuhi persyaratan tertentu untuk dapat menghasilkan pekerjaan sesuai kualitas yang dituntut suatu pekerjaan tertentu. Setiap pekerjaan mempunyai standar kualitas tertentu yang harus disesuaikan oleh karyawan untuk dapat mengerjakannya sesuai ketentuan. Karyawan memiliki kinerja baik bila dapat menghasilkan pekerjaan sesuai persyaratan kualitas yang dituntut pekerjaan tersebut.

3) Ketepatan waktu, yaitu setiap pekerjaan memiliki karakteristik yang berbeda. Untuk jenis pekerjaan tertentu harus diselesaikan tepat waktu, karena memiliki ketergantungan atas pekerjaan lainnya. Jadi, bila pekerjaan pada suatu bagian tertentu tidak selesai tepat waktu akan menghambat pekerjaan pada bagian lain, sehingga mempengaruhi jumlah dan kualitas hasil pekerjaan. Pada dimensi ini, karyawan dituntut untuk dapat menyelesaikan pekerjaan tepat waktu. Selain penyelesaian kerja dengan tepat waktu, karyawan juga diharuskan untuk datang tepat pada waktunya, karena salah satu faktor pekerjaan yang dilakukan cepat selesai ini sesuai dengan waktu yang ditentukan. Apabila karyawan mengalami keterlambatan akan berdampak waktu pekerjaannya akan berkurang dan pekerjaannya tidak akan selesai sesuai dengan waktunya.

4) Kehadiran, yaitu suatu jenis pekerjaan tertentu menuntut kehadiran karyawan dalam mengerjakannya sesuai waktu yang ditentukan. Ada tipe pekerjaan yang menuntut kehadiran karyawan selama delapan jam sehari untuk lima hari kerja seminggu. Kinerja karyawan ditentukan oleh tingkat kehadiran karyawan dalam mengerjakannya.

5) Kemampuan kerja sama, dimana tidak semua pekerjaan dapat diselesaikan oleh satu orang karyawan saja. Untuk jenis pekerjaan tertentu mungkin harus diselesaikan oleh dua orang karyawan atau lebih, sehingga membutuhkan kerja sama antar karyawan sangat dibutuhkan. Kinerja karyawan dapat dinilai dari kemampuannya bekerjasama dengan rekan sekerja lainnya.

- Fleksibilitas Kerja

Salah satu strategi yang dilakukan oleh organisasi untuk mempertahankan para karyawan adalah dengan memberikan fleksibilitas kerja atau Flexible Work Arrangements (FWA). Fleksibilitas kerja diberikan sebagai bentuk variasi ketika bekerja, sehingga membuat para pekerja tidak merasa bosan. Flexible working dapat menurunkan konflik antara pekerjaan dan keluarga, menurunkan stres kerja yang dapat mempengaruhi performa individu yang dapat mengakibatkan berkurangnya turnover terutama pada pekerja wanita yang pada akhirnya akan memilih meneruskan tanggung jawab keluarga dibanding bertahan pada pekerjaan dan mengabaikan komitmen terhadap keluarga.

Fleksibilitas Kerja atau Flexible Working Arrangement adalah jadwal yang 
memungkinkan pegawai dapat mengatur fleksibilitas jam kerjanya dengan tanggung jawab pribadi mereka, misalnya berapa lama, dimana, dan kapan mereka mulai bekerja. Contoh lainnya adalah flex-time, job-sharing, part-time, home working, dan compressed hour (Carlson et al., 2010). Pemberian fleksibilitas kerja memberi keuntungan pada organisasi maupun anggota organisasi. Untuk organisasi, pemberian fleksibilitas kerja dapat memikat, mendapatkan, dan mempertahankan anggota organisasi dengan kualitas yang baik di dalam organisasi mereka (Pandiangan, 2018).

\section{- Indikator Fleksibilitas Kerja}

Norgate dan Cooper (2020) menyatakan bahwa schedule flexibility adalah pengaturan kerja secara fleksibel yang berarti pemilihan tempat dan waktu untuk bekerja, baik formal atau informal, yang memfasilitasi karyawan dalam kebijakan berapa lama (time flexibility), kapan (timing flexibility), dan di mana (place flexibility) karyawan bekerja.

a. Time flexibility: fleksibilitas karyawan dalam memodifikasi durasi kerja.

b. Timing flexibility: fleksibilitas karyawan dalam memilih jadwal kerjanya.

c. Place flexibility: fleksibilitas karyawan dalam memilih tempat kerjanya.

- Fleksibilitas Kerja di BSSN

Penerapan flexitime di BSSN dilaksanakan melalui Surat Edaran Nomor 5 Tahun 2019 pada tanggal 18 April 2019 Tentang Penggantian Waktu Keterlambatan dan Kehadiran Pegawai di Lingkungan Badan Siber dan Sandi Negara. Toleransi keterlambatan maksimal 15 (lima belas) menit dimulai dari pukul 07.30 - 07.45 WIB, dengan mengganti keterlambatan pada hari yang sama minimal sejumlah waktu keterlambatan yang dilaksanakan setelah jam kerja, mulai tanggal 22 April 2019.

BSSN juga menerapkan sistem kerja Work From Home (WFH) selama periode 14 (empat belas) hari kalender yang diperpanjang sampai saat ini dalam rangka melindungi kesehatan dan keselamatan pegawai akibat pandemi Corona Virus Disease 2019 (Covid-19) yang telah menjadi masalah kesehatan dunia sebagaimana pernyataan World Health Organization (WHO) tanggal 26 Februari 2020, yang kemudian ditindaklanjuti dengan Surat Edaran Nomor 6 Tahun 2020 Tentang Upaya Pencegahan Penyebaran Covid-19 di lingkungan BSSN.

- Keseimbangan Kehidupan Kerja

Keseimbangan kehidupan kerja atau work-life balance dapat didefinisikan sebagai keseimbangan antara pekerjaan dan kehidupan pribadi. Istilah work-life balance mulai dikenal pertama kali oleh masyarakat Inggris pada akhir tahun 1970an. Dalam Encyclopedia of Management work-life balance didefinisikan dalam dua pandangan yang pandangan yang berbeda yaitu: pertama, karyawan; work-life balance dipahami sebagai pengelolaan kewajiban dalam pekerjaan dan tanggung jawab kehidupan pribadi. Kedua, atasan; work-life balance dapat dipahami sebagai tantangan untuk menciptakan budaya perusahaan yang mendukung para karyawan agar tetap fokus dalam pekerjaannya. Parkes \& Langford (2008) mendefinisikan 
work life balance sebagai individu yang mampu berkomitmen dalam pekerjaan dan keluarga, serta bertanggungjawab baik dalam kegiatan non-pekerjaan. Dalam menyelaraskan kedua hal tersebut dibutuhkan adanya keseimbangan, banyak karyawan yang kesulitan dalam mengatur baik dalam bekerja maupun dalam kesehatannya sendiri.

- Indikator Keseimbangan Kehidupan Kerja

Work life balance menurut Fisher et al., (2009) memiliki 4 dimensi pembentuk, yaitu:

a. WIPL (Work Interference With Personal Life)

Dimensi ini mengacu pada sejauh mana pekerjaan dapat mengganggu kehidupan pribadi individu. Misalnya, bekerja dapat membuat seseorang sulit mengatur waktu untuk kehidupan pribadinya.

b. PLIW (Personal Life Interference With Work)

Dimensi ini mengacu pada sejauh mana kehidupan pribadi individu mengganggu kehidupan pekerjaannya. Misalnya, apabila individu memiiliki masalah didalam kehidupan pribadinya, hal ini dapat mengganggu kinerja individu pada saat bekerja.

c. PLEW (Personal Life Enhancement Of Work)

Dimensi ini mengacu pada sejauh mana kehidupan pribadi seseorang dapat meningkatkan performa individu dalam dunia kerja. Misalnya, apabila individu merasa senang dikarenakan kehidupan pribadinya menyenangkan maka hal ini dapat membuat suasana hati individu pada saat bekerja menjadi menyenangkan.

d. WEPL (Work Enhancement Of Personal Life)

Dimensi ini mengacu pada sejauh mana pekerjaan dapat meningkatkan kualitas kehidupan pribadi individu. Misalnya keterampilan yang diperoleh individu pada saat bekerja, memungkinkan individu untuk memanfaatkan keterampilan tersebut dalam kehidupan sehari-hari.

Untuk mendukung keseimbangan kehidupan kerja BSSN telah menyediakan fasilitas, di antaranya: Akses mudah untuk olahraga dimana pekerja bisa berolahraga untuk hidup sehat secara rutin dengan fasilitas on-site gym di area kantor, track lari, lapangan tenis, lapangan badminton, lapangan futsal, serta kolam renang untuk para pegawainya. Selain itu terdapat jam krida pada hari Jumat pagi, dimana pegawai dapat secara bebas berolahraga apa pun pada waktu tersebut.

Selain itu pegawai BSSN mendapatkan hak untuk melaksanakan cuti untuk mendukung kebutuhan pegawai sesuai Peraturan Badan Kepegawaian Negeri Republik Indonesia Nomor 24 Tahun 2017 tentang Tata Cara Pemberian Cuti Pegawai Negeri Sipil (PNS). Adapun macam-macam cuti PNS adalah: cuti tahunan; cuti besar; cuti sakit; cuti melahirkan; cuti karena alasan penting; cuti bersama; dan cuti di luar tanggungan negara.

BSSN juga memberikan kesempatan bagi pegawai wanita yang sedang menyusui untuk memerah ASI pada waktu kerja di tempat kerja sesuai Peraturan Menteri Kesehatan Republik Indonesia Nomor 15 Tahun 2013 Tentang Tata Cara 
Penyediaan Fasilitas Khusus Menyusui dan/atau Memerah Air Susu Ibu. BSSN menyediakan ruang menyusui sesuai standar yang memenuhi persyaratan Kesehatan di setiap Gedung di lingkungan BSSN, dimana ruang laktasi ini dikoordinir oleh Korpri BSSN.

Pegawai BSSN baik yang sudah berkeluarga ataupun belum pada segmen tertentu yang belum memiliki tempat tinggal tetap atau tempat tinggal berlokasi jauh dari kantor BSSN, dapat memanfaatkan Rumah Susun Sederhana Sewa (Rusunawa) yang berlokasi di sekitar kantor BSSN dengan harga sewa yang sangat terjangkau. Rusunawa ini mendukung work life balance karena dapat membuat pegawai dekat dengan keluarga.

Fasilitas lainnya yang mendukung work life balance pegawai adalah mobil jemputan. BSSN menyediakan mobil jemputan dari kantor BSSN di ragunan ke kantor BSSN di Sawangan, Ciseeng dan Sentul setiap hari kerja.

\section{- Penghargaan (Reward)}

Reward merupakan salah satu elemen yang dapat dimanfaatkan organisasi untuk memotivasi karyawan agar dapat memberikan kontribusi yang maksimal. Pemberian reward tersebut merupakan upaya pemimpin dalam memberikan balas jasa atas hasil kerja pegawai, sehingga dapat mendorong bekerja lebih giat dan berpotensi. Penghargaan (reward) memiliki pemahaman penghargaan/imbalan yang diberikan organisasi kepada anggotanya, baik yang sifatnya materi finansial, materi non finansial, maupun psikis atau non materi. Wujud dari penghargaan dapat berupa gaji pokok/upah dasar, gaji variabel, insentif, uang jasa prestasi (bonus), kesempatan karier/promosi, liburan, pensiun (Prabu dan Wijayanti, 2016).

- Indikator Penghargaan

Penelitian yang dilakukan Schuler (dalam Nitisemito, 2001) menyatakan terdapat tiga indikator untuk mengukur penghargaan, yaitu:

a. Penghargaan ekstrinsik langsung, diantaranya adalah gaji, insentif, bonus. Menurut Armstrong \& Murlis (2007) upah atau gaji diartikan juga sebagai pembayaran dalam bentuk uang secara tunai atau berupa natura yang diperoleh pekerja untuk pelaksanaan pekerjaannya. Menurut Nawawi (1997) gaji diartikan juga sebagai harga untuk jasa-jasa yang telah diberikan oleh seseorang kepada orang lain. Fungsi upah adalah sebagai jaminan kelangsungan kehidupan yang layak bagi kemanusiaan dan produksi yang dinyatakan atau dinilai dalam bentuk uang.

b. Penghargaan ekstrinsik tidak langsung, yaitu pemberian bagian keuntungan/manfaat lainnya bagi para pekerja di luar gaji atau upah tetap, dapat berupa uang atau barang. Kompensasi tidak langsung juga dikatakan sebagai pemberian keuntungan organisasi, misalnya THR, pemberian jaminan kesehatan, liburan, cuti dan lain-lain (Nawawi, 1997).

c. Penghargaan intrinsik. Kebutuhan intrinsik atau non finansial mencakup: 1) pencapaian, didefinisikan sebagai keberhasilan kompetitif yang diukur berdasarkan standar keunggulan pribadi; 2) pengakuan, dimana penghargaan ini jangan sampai disampaikan dalam bentuk pengakuan semata. Tindakan 
lain yang merupakan bentuk pengakuan mencakup promosi, penempatan pada proyek bergengsi, perluasan pekerjaan yang lebih menarik dan menguntungkan, dan berbagai symbol status dan kebanggaan; 3) tanggung jawab, yaitu pemberian tanggung jawab ini sejalan dengan motivasi intrinsik yang didasarkan pada isi jabatan; 4) pengaruh, yaitu oganisasi melalui kebijakan partisipasi bisa memotivasi orang dengan cara memberi kesempatan untuk mengungkapkan gagasannya, kesempatan agar pandangannya didengar dan bertindak sesuai pandangannya tersebut, dan; 5) pertumbuhan diri/ perkembangan karir, dimana orang yang ambisius dan berkeyakinan tinggi akan mencari dan menemukan peluang untuk dirinya sendiri, meskipun organisasi telah menetapkan lingkup pertumbuhan dan pengembangan yang bisa disediakan (Armstrong dan Murlis, 2007).

Terdapat mekanisme untuk pemberian penghargaan pegawai di Badan Siber dan Sandi Negara sebagai imbalan atas kinerja ataupun pengabdian selama bekerja di BSSN, yaitu:

1) Tunjangan Kinerja, dimana ketentuannya sesuai dengan Peraturan Badan Siber dan Sandi Negara Nomor 3 Tahun 2020 Tentang Pelaksanaan Pemberian Tunjangan Kinerja Bagi Pegawai di Lingkungan Badan Siber dan Sandi Negara, maka seluruh PNS, TNI \& Polri di BSSN diberikan tunjangan kinerja sesuai dengan Capaian Kinerja Pegawai (CKP) yang sejalan dengan Nilai Kinerja Organisasi BSSN serta kehadiran pegawai tersebut.

2) Tanda Kehormatan Satyalancana Karya Satya (SLKS), yaitu berdasarkan Peraturan Pemerintah Republik Indonesia Nomor 25 Tahun 1994 tentang Tanda Kehormatan Tanda Satyalancana Karya Satya yang menyatakan bahwa penganugerahan Satyalancana Karya Satya merupakan penghargaan dari negara terhadap PNS yang telah bekerja dengan penuh kesetiaan kepada Pancasila, Undang-Undang Dasar 1945, Negara dan pemerintah serta penuh dengan pengabdian, kejujuran, kecakapan dan disiplin, sehingga dapat dijadikan teladan bagi pegawai yang lainnya. Pegawai BSSN yang dalam melaksanakan tugasnya menunjukkan kesetiaan, pengabdian, kecakapan, kejujuran, dan kedisiplinan serta telah bekerja terus menerus sekurangkurangnya 10 tahun, 20 tahun, dan 30 tahun berhak diberikan penghargaan SLKS.

3) Tanda Penghargaan di Bidang Keamanan Siber, yaitu warga negara Indonesia yang berkinerja, berinovasi, mengembangkan atau memajukan bidang keamanan siber dan persandian, memiliki kesempatan setara untuk dapat dipertimbangkan memperoleh penghargaan oleh Badan Siber dan Sandi Negara dalam rangka meningkatkan kinerja, menumbuhkan inovasi, menumbuhkan kebanggaan, sikap keteladanan, semangat kejuangan, dan motivasi dalam memajukan bidang keamanan siber dan persandian. Adapun jenis penghargaan tersebut terdiri dari:

a. Sanapati Teladan, diberikan kepada pegawai yang bekerja di bidang keamanan siber dan/atau persandian atas kinerja, inovasi, kontribusi, 
dan pengabdian yang luar biasa di bidang keamanan siber dan/atau persandian Instansi Pemerintah.

b. Tokoh Inspiratif Keamanan Siber dan Sandi, diberikan kepada warga negara Indonesia atas jasa dan dharma bakti kepada bangsa dan negara dalam bentuk karya inovasi, kontribusi kreatif, dan/atau pembangunan yang signifikan di bidang keamanan siber dan/atau persandian.

c. Adibhakti Sanapati, diberikan kepada warga negara Indonesia atas jasa dan dharma bakti yang luar biasa sepanjang hidupnya kepada bangsa dan negara di bidang keamanan siber dan/atau persandian.

d. Dharma Persandian, diberikan kepada pegawai atas pengabdian dan kesetiaan di bidang persandian selama 10, 20 dan 30 Tahun.

- Lingkungan Kerja Non Fisik

Menurut Nitisemito (2001), lingkungan kerja adalah segala sesuatu yang ada disekitar para pekerja dan yang dapat mempengaruhi dirinya dalam menjalankan tugas-tugas yang dibebankan. Perusahaan hendaknya dapat mencerminkan kondisi yang mendukung kerja sama antara tingkat atasan, bawahan maupun yang memiliki status jabatan yang sama di perusahaan. Kondisi yang hendaknya diciptakan adalah suasana kekeluargaan, komunikasi yang baik, dan pengendalian diri. Adapun indikator lingkungan kerja meliputi:

a. Suasana kerja, yaitu kondisi yang ada di sekitar karyawan yang sedang melakukan pekerjaan yang dapat memengaruhi pelaksanaan pekerjaan itu sendiri.

b. Hubungan dengan rekan kerja, yaitu Hubungan dengan rekan kerja yaitu hubungan dengan rekan kerja harmonis dan tanpa ada saling intrik diantara sesama rekan sekerja.

c. Hubungan antara bawahan dengan pimpinan, yaitu hubungan hubungan dengan karyawan yang baik dan harmonis dengan pimpinan tempat kerja.

d. Tersedianya fasilitas kerja, dimana hal ini dimaksudkan bahwa peralatan yang digunakan untuk mendukung kelancaran kerja lengkap/mutakhir.

\section{METODOLOGI}

\section{Kerangka Model}

Kerangka model merupakan diagram yang menjelaskan model penelitian beserta teori-teori yang digunakan untuk menyusun indikator kuisioner. Kerangka model dalam penelitian ini adalah sebagaimana digambarkan pada Gambar 1. 


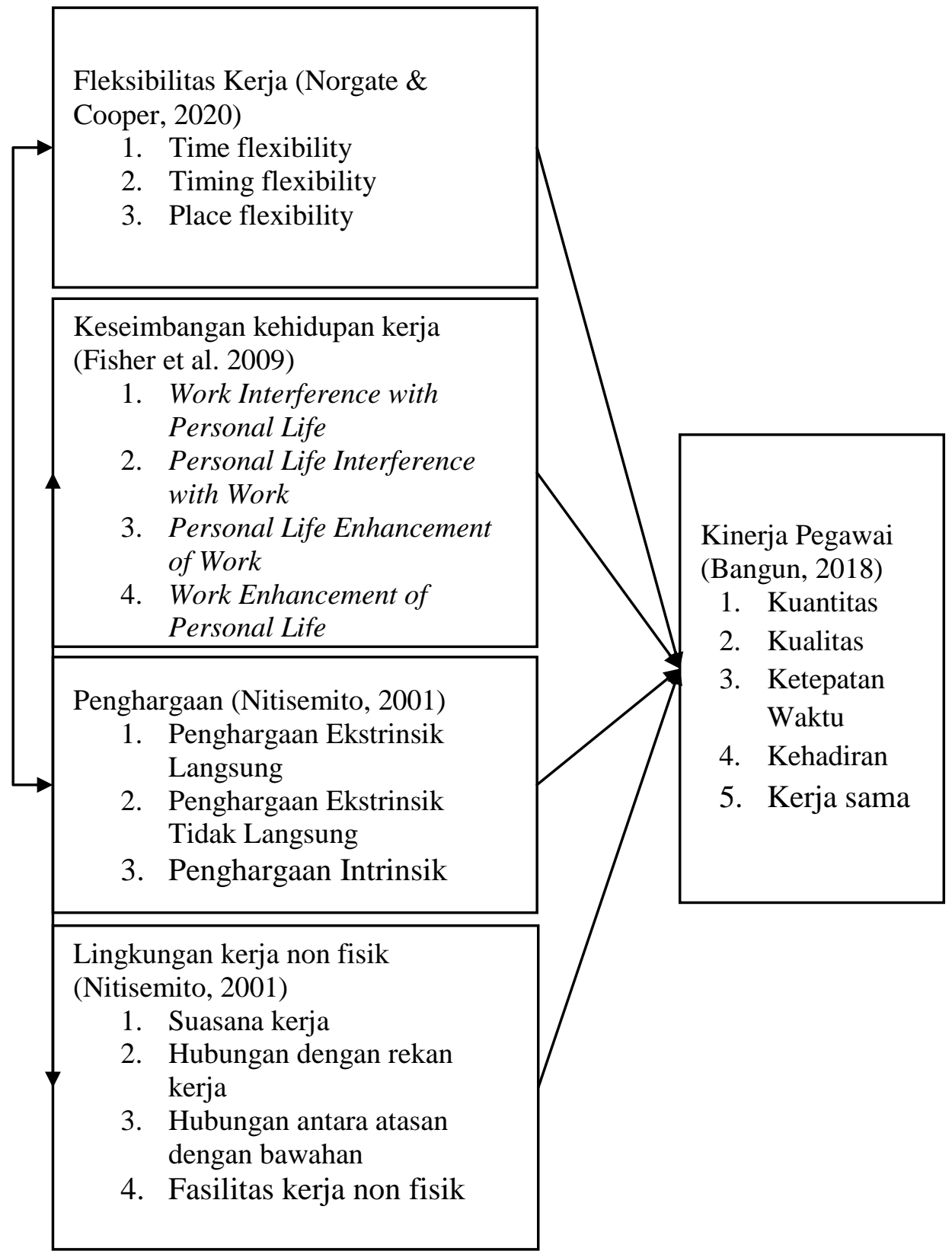

Gambar 1. Kerangka Model Penelitian

\section{Hipotesis}

Hipotesis penelitian merupakan suatu pemikiran sementara yang dihasilkan dalam upaya mencari suatu pembenaran atas jalan keluar dalam suatu permasalahan penelitian. Hipotesis yang diajukan dalam penelitian ini adalah: 
H1 : Fleksibilitas kerja berpengaruh positif dan signifikan terhadap kinerja pegawai.

H2 : Keseimbangan kehidupan kerja berpengaruh positif dan signifikan terhadap kinerja pegawai.

H3 : Penghargaan berpengaruh positif dan signifikan terhadap kinerja pegawai.

H4 : Lingkungan kerja non fisik berpengaruh positif dan signifikan terhadap kinerja pegawai.

\section{Metode Penelitian}

Penelitian ini menggunakan pendekatan statistik deskriptif dan statistik inferensial. Statistik deskriptif bertujuan untuk memberikan deskripsi mengenai objek penelitian berdasarkan data yang diperoleh dari kelompok yang diteliti dan tidak dimaksudkan untuk menguji hipotesis. Sedangkan statistik inferensial bertujuan untuk mengambil kesimpulan, yaitu dengan cara pengujian hipotesis yang telah diajukan. Pada penelitian ini pendekatan statistik inferensial yang digunakan adalah analisis regresi linier, untuk mengetahui hubungan fungsional di antara variabel independen (Fleksibilitas Jam Kerja, Keseimbangan Kehidupan Kerja, Penghargaan, Lingkungan Kerja Non Fisik dengan variabel dependen adalah Kinerja Pegawai. Persamaan regresi linier ganda dalam penelitian ini menggunakan rumusan:

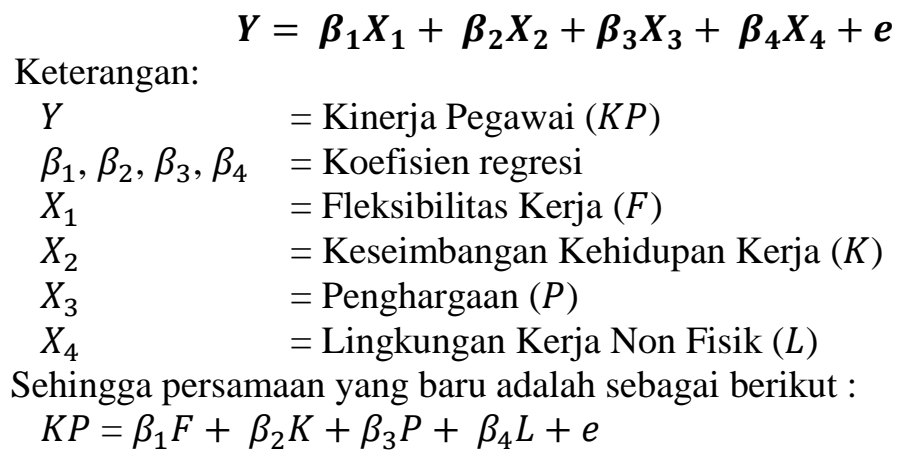

\section{Populasi dan Sampel}

Populasi pada penelitian ini adalah seluruh pegawai BSSN yang berjumlah 1099 orang. Bila populasi besar, maka dimungkinkan untuk menggunakan sampel yang diambil dari populasi ini (Ghozali, 2017). Indikator dalam penelitian ini sebanyak 19 indikator, sampel pada penelitian ini adalah 10 x 19 atau sebesar 190 pegawai sebagai responden yang telah bekerja di BSSN minimal 1 tahun pada Januari 2020. Metode pengambilan sampel yang digunakan pada penelitian ini adalah accidental sampling (sampling aksidental).

\section{Metoda Analisis}

Metode analisis data yang digunakan dalam penelitian ini yaitu metode analisis inferensial dengan menggunakan alat analisis Structural Equation Model (SEM) melalu software AMOS versi 22. Structural Equation Model (SEM) 
merupakan teknik statistik multivariate yang merupakan kombinasi antara analisis faktor dan analisis regresi (korelasi), yang bertujuan untuk menguji hubunganhubungan antar variabel yang ada pada sebuah model, baik itu antar indikator dengan konstruknya, ataupun hubungan antar konstruk. Adapun indeks kesesuaian model goodness of fit pada penelitian ini sebagaimana dinyatakan pada Tabel 3.

Tabel 3. Goodness of Fit Index

\begin{tabular}{|l|l|l|}
\hline Alat Uji Statistik & Kriteria & Kesimpulan \\
\hline Chi-Squre $\left(\mathrm{X}^{2}\right)$ & $\mathrm{X}^{2}<\mathrm{X}^{2}$ tabel & Good Fit \\
\hline Taraf Signifikan $(\mathrm{a})$ & $\mathrm{P}-$ Value $\geq \mathrm{a}$ & Good Fit \\
\hline CMIN/ df & $\leq 2,00$ & Good Fit \\
\hline RMSEA & $\leq 0,08$ & Good Fit \\
\hline TLI & $\geq 0,90$ & Good Fit \\
\hline NFI & $\geq 0,90$ & Good Fit \\
\hline IFI & $\geq 0,90$ & Good Fit \\
\hline PNFI & $\geq 0,60$ & Good Fit \\
\hline
\end{tabular}

Sumber: Ghozali (2011), Santoso (2002)

\section{HASIL}

- Uji Kelayakan Full Model

Uji perbandingan antara matriks kovarian sampel dengan matriks kovarian estimasi disebut uji goodness of fit. Goodness of fit bertujuan untuk menguji apakah model yang dihasilkan menggambarkan kondisi aktualnya. Hipotesis dilakukan dengan langkah-langkah sebagai berikut.

H0 : Model tidak goodness of fit artinya model yang dihasilkan tidak menggambarkan kondisi aktualnya.

H1 : Model goodness of fit artinya model yang dihasilkan menggambarkan kondisi aktualnya.

Kriteria pengujian terdiri dari tiga jenis, yaitu absolute fit indices, incremental fit indices dan parsimony fit indices. Hasil uji goodness of fit untuk CFA full model dinyatakan pada Tabel 4 .

Tabel 4. Goodness Of Fit Index untuk CFA Full Model

\begin{tabular}{|l|l|l|l|}
\hline No & $\begin{array}{l}\text { Goodness Of Fit } \\
\text { Index }\end{array}$ & Cut Off (nilai batas) & Kesimpulan \\
\hline 1. & DF & $142>0$ & Good Fit \\
\hline 2. & $\begin{array}{l}X^{2} \text { Chi-Square } \\
\text { Significance } \\
\text { Probability }\end{array}$ & $167,388<170,8092$ & \\
\cline { 2 - 3 } 3. & CMIN/df & $0,072 \geq 0,05$ & \\
\hline 4. & GFI & $0,880 \geq 0,90$ & Good Fit \\
\hline 5. & AGFI & $0,840 \geq 0,90$ & Marginal \\
\hline 6. & CFI & $0,993 \geq 0,95$ & Good Fit \\
\hline
\end{tabular}




\begin{tabular}{|l|l|l|l|}
\hline 7. & TLI & $0,992 \geq 0,95$ & Good Fit \\
\hline 8. & NFI & $0,957 \geq 0,90$ & Good Fit \\
\hline 9. & IFI & $0,993 \geq 0,90$ & Good Fit \\
\hline 10. & RMSEA & $0,036<0,08$ & Closed Fit \\
\hline
\end{tabular}

Sumber: Hasil Olahan AMOS 24

Hasil uji goodness of fit pada Tabel 4 menunjukkan bahwa model mayoritas berada dalam kategori good fit. Sehingga dapat dikatakan bahwa model yang diajukan bersifat fit (Solimun et al., 2017). Dengan demikian dapat diartikan bahwa model yang dihasilkan menggambarkan kondisi aktualnya dan tidak perlu dilakukan perbaikan model.

- Analisis Model Struktural

Setelah uji confirmatory factor analysis dan uji kelayakan full model, tahapan selanjutnya adalah melihat pengaruh dan hubungan variabel laten eksogen dan endogen. Hasil pengolahan data adalah diagram yang menghubungkan antara variabel eksogen, perantara dan endogen. Anak panah-anak panah tunggal menunjukkan hubungan sebab-akibat antara variabel-variabel eksogen, atau perantara dengan variabel endogen. Anak panah juga menghubungkan kesalahan (residue).

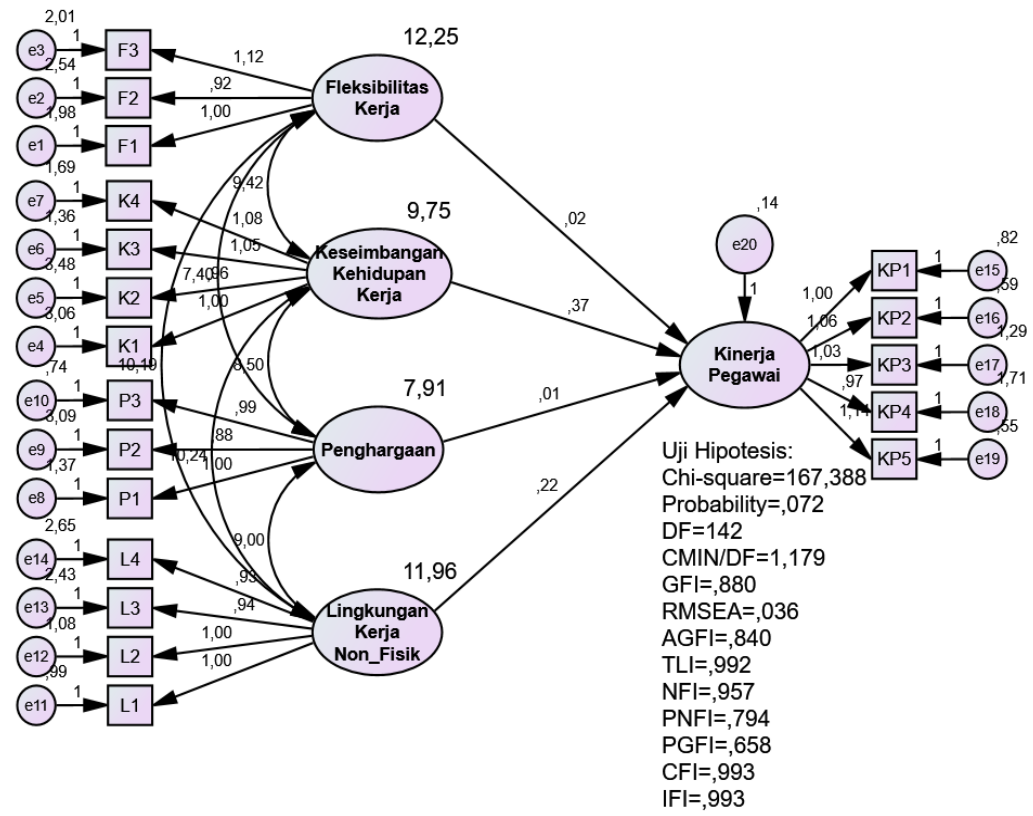

Gambar 2. Full Model Penelitian 
Anak panah ganda pada Gambar 2 menunjukkan korelasi antara pasangan variabel-variabel exogenous. Koefesien jalur adalah koefesien regresi standar atau disebut 'beta' yang menunjukkan pengaruh langsung dari suatu variabel eksogen terhadap variabel endogen. Adapun Standardized Regression Weights antar variabel adalah sebaimana dinyatakan pada Tabel 5 .

Tabel 5. Standardized Regression Weights antar variabel

\begin{tabular}{|c|c|}
\hline & Estimate \\
\hline Kinerja_Pegawai <--- & ,201 \\
\hline Kinerja_Pegawai <--- Keseimbangan_Kehidupan_Kerja & ,221 \\
\hline Kinerja_Pegawai <--- Penghargaan & , 260 \\
\hline Kinerja_Pegawai <--- Lingkungan_Kerja_Non_Fisik & , 160 \\
\hline
\end{tabular}

Sumber: Hasil Olahan AMOS 24

Persamaan struktural Kinerja Pegawai (KP) menjelaskan hubungan kausal antara perubahan KP apabila terjadi perubahan variabel bebasnya, yaitu Fleksibilitas Kerja (F), Keseimbangan Kehidupan Kerja (K), Penghargaan (P) dan Lingkungan Kerja Non Fisik (L) atau KP = f (F, K, P, L).

Tabel 6. Squared Multiple Correlations

\begin{tabular}{|l|l|}
\hline & Estimate \\
\hline Kinerja_Pegawai &, 966 \\
\hline
\end{tabular}

Sumber: Hasil Pengujian AMOS versi 24

Tabel 6 menunjukkan bahwa nilai $R$ Square sebesar 0,966 atau 96,6\%. Hal tersebut bisa diartikan bahwa 96,6\% kinerja pegawai BSSN dapat dijelaskan oleh variabel fleksibilitas kerja, keseimbangan kehidupan kerja, penghargaan dan lingkungan kerja non fisik, sedangkan sisanya sebesar 3,4\% dijelaskan oleh variabel-variabel lain di luar model struktural yang tidak dibahas didalam penelitian ini. Nilai $R$ Square dalam penelitian ini sangat kuat, sehingga bisa dikatakan bahwa fleksibilitas kerja, keseimbangan kehidupan kerja, penghargaan dan lingkungan kerja non fisik berpengaruh erat terhadap kinerja pegawai BSSN. Dengan demikian, persamaan struktural variabel eksogen terhadap variabel endogen adalah sebagai berikut :

$$
\begin{aligned}
& K P=\beta_{1} F+\beta_{2} K+\beta_{3} P+\beta_{4} L+e \\
& K P=0,201 F+0,221 K+0,260 P+0,160 L
\end{aligned}
$$

$$
\begin{array}{ll}
\text { Keterangan: } & \\
K P & =\text { Variabel dependen (Kinerja Pegawai) } \\
\beta_{1}, \beta_{2}, \beta_{3}, \beta_{4} & =\text { Koefisien regresi } \\
F & =\text { Variabel independent Fleksibilitas Jam Kerja } \\
K & =\text { Variabel independent Keseimbangan Kehidupan Kerja }
\end{array}
$$




$$
\begin{array}{ll}
P & =\text { Variabel independent Penghargaan } \\
L & =\text { Variabel independent Lingkungan Kerja Non Fisik } \\
e & =\text { error }
\end{array}
$$

Dengan melihat persamaan regresi linier (struktural) di atas, dapat dijelaskan bahwa:

a. Faktor dominan yang mempengaruhi kinerja pegawai BSSN adalah variabel penghargaan, hal ini dapat dilihat dari nilai koefisien dari variabel penghargaan sebesar 0,260, diikuti keseimbangan kehidupan kerja dengan nilai koefisien 0,221, fleksibilitas kerja dengan nilai koefisien sebesar 0,201 dan lingkungan kerja non fisik dengan nilai koefisien sebesar 0,160 .

b. Nilai koefisien regresi fleksibilitas kerja sebesar 0,201. Hal ini berarti bahwa setiap kenaikan fleksibilitas kerja positif maka variabel kinerja pegawai akan naik sebesar 0,201 dengan asumsi bahwa variabel bebas yang lain dari persamaan struktural adalah tetap.

c. Nilai koefisien regresi keseimbangan kehidupan kerja sebesar 0,221. Hal ini menunjukkan bahwa setiap kenaikan keseimbangan kehidupan kerja positif maka variabel kinerja pegawai akan naik sebesar 0,221 dengan asumsi bahwa variabel bebas yang lain dari persamaan struktural adalah tetap.

d. Nilai koefisien regresi penghargaan adalah sebesar 0,260. Hal ini mengandung arti bahwa setiap kenaikan penghargaan positif maka variabel kinerja pegawai akan naik sebesar 0,260 dengan asumsi bahwa variabel bebas yang lain dari persamaan regresi adalah tetap.

e. Nilai koefisien regresi lingkungan kerja non fisik adalah sebesar 0,160. Hal berarti bahwa setiap kenaikan lingkungan kerja non fisik positif maka variabel kinerja pegawai akan naik sebesar 0,160 dengan asumsi bahwa variabel bebas yang lain dari persamaan regresi adalah tetap.

\section{Uji Hipotesis}

Kriteria goodness of fit model struktural yang diestimasi dapat terpenuhi, karenanya tahap berikut adalah analisis terhadap hubungan struktural model (uji hipotesis). Hubungan antar konstruk dalam hipotesis ditunjukkan oleh nilai regression weight (Hair et al, 1998 dalam Haryono dan Hastjarjo, 2010). Uji hipotesis dilakukan untuk merngetahui berpengaruh atau tidaknya variabel independen terhadap variabel dependen. Hipotesis dinyatakan diterima jika nilai prob $(\mathrm{P})<0,05$ atau $\mathrm{CR}>1,96$ (nilai Zkritis untuk derajat kepercayaan 95\%). Hasil

\begin{tabular}{|c|c|c|c|c|c|c|c|}
\hline & & & Estimate & S.E. & C.R. & $P$ & Label \\
\hline Kinerja_Pegawai & & Fleksibilitas_Kerja &, 171 &, 047 & 3,642 & $* * *$ & par_15 \\
\hline Kinerja_Pegawai & $<-$ & Keseimbangan_Kehidupan_Kerja &, 173 & ,043 & 3,981 & $* * *$ & par_16 \\
\hline Kinerja_Pegawai & $<-$ & Penghargaan & ,280 & ,062 & 4,501 & $* * *$ & par_17 \\
\hline
\end{tabular}
uji hipotesis dapat dilihat pada Tabel 7.

Tabel 7. Unstandardized Regression Weights 


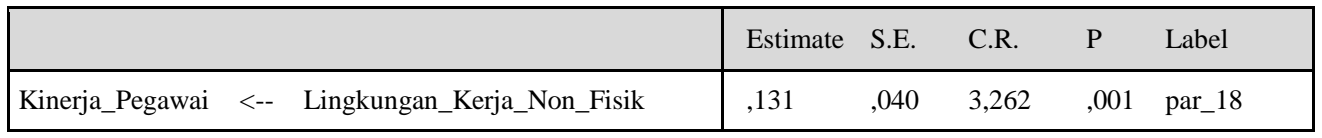

Sumber: Hasil Olahan AMOS 24

Dari hasil pengujian terhadap seluruh hipotesis yang diajukan dalam penelitian ini, maka dapat dinyatakan bahwa:

\section{- Pengaruh Fleksibilitas Kerja terhadap Kinerja Pegawai BSSN}

H1 : Fleksibilitas Kerja berpengaruh positif dan signifikan terhadap Kinerja Pegawai

Pendapat responden tentang pengaruh variabel fleksibilitas kerja terhadap kinerja pegawai adalah sebesar 3,642 > 1,96 (nilai Zkritis untuk derajat kepercayaan $95 \%$ ) dengan nilai probabilitas (p) sebesar $0,00<0,05$ dan nilai koefisien regresi pengaruh sebesar 0,201 (positif), sehingga dapat disimpulkan bahwa H1 diterima dan semakin tinggi fleksibilitas kerja maka kinerja pegawai akan semakin tinggi begitu juga sebaliknya.

- $\quad$ Pengaruh Keseimbangan Kehidupan Kerja terhadap Kinerja Pegawai BSSN

H2 : Keseimbangan Kehidupan Kerja berpengaruh positif dan signifikan terhadap Kinerja Pegawai

Pendapat responden tentang pengaruh variabel keseimbangan kehidupan kerja terhadap kinerja pegawai adalah sebesar 3,981 > 1,96 (nilai Zkritis untuk derajat kepercayaan 95\%) dengan nilai probabilitas (p) sebesar $0,00<0,05$ dan nilai koefisien regresi pengaruh sebesar 0,221 (positif), sehingga dapat disimpulkan bahwa $\mathrm{H} 2$ diterima dan semakin tinggi keseimbangan kehidupan kerja maka kinerja pegawai akan semakin tinggi begitu juga sebaliknya.

- Pengaruh Penghargaan terhadap Kinerja Pegawai BSSN

H3 : Penghargaan berpengaruh positif dan signifikan terhadap Kinerja Pegawai

Pendapat responden tentang pengaruh variabel penghargaan terhadap kinerja pegawai adalah sebesar 4,5>1,96 (nilai Zkritis untuk derajat kepercayaan 95\%) dengan nilai probabilitas (p) sebesar $0,00<0,05$ dan nilai koefisien regresi pengaruh sebesar 0,16 (positif), sehingga dapat disimpulkan bahwa $\mathrm{H} 3$ diterima dan semakin tinggi lingkungan kerja non fisik penghargaan maka kinerja pegawai akan semakin tinggi begitu juga sebaliknya.

- $\quad$ Pengaruh Lingkungan Kerja Non Fisik terhadap Kinerja Pegawai BSSN

H4 : Lingkungan Kerja Non Fisik berpengaruh positif dan signifikan terhadap Kinerja Pegawai

Pendapat responden tentang pengaruh variabel lingkungan kerja non fisik terhadap kinerja pegawai adalah sebesar 3,262 > 1,96 (nilai Zkritis untuk derajat kepercayaan 95\%) dengan nilai probabilitas (p) sebesar 0,001<0,05 dan nilai koefisien regresi pengaruh sebesar 0,16 (positif), sehingga dapat disimpulkan bahwa 
H4 diterima dan semakin tinggi lingkungan kerja non fisik maka kinerja pegawai akan semakin tinggi begitu juga sebaliknya.

Dari hasil uji hipotesis maka dapat dinyatakan bahwa variabel fleksibilitas kerja, keseimbangan kehidupan kerja, penghargaan dan lingkungan kerja non fisik masing-masing berpengaruh terhadap kinerja pegawai di lingkungan Badan Siber dan Sandi Negara. Selanjutnya 4 hipotesis dalam penelitian ini dapat diterima.

\section{PEMBAHASAN}

Berdasarkan hasil pengujian, maka bisa penjelasan dan pembahasan atas hasil penelitian tersebut bisa diuraikan sebagai berikut:

- Pengaruh Fleksibilitas Kerja terhadap Kinerja Pegawai BSSN.

Pendapat responden tentang pengaruh variabel fleksibilitas kerja terhadap kinerja pegawai adalah sebesar 3,642 > 1,96 (nilai Zkritis untuk derajat kepercayaan $95 \%$ ) dengan nilai probabilitas (p) sebesar $0,00<0,05$ dan nilai koefisien regresi pengaruh sebesar 0,201 (positif). Dengan demikian dapat disimpulkan bahwa H0 diterima dan semakin tinggi fleksibilitas kerja maka kinerja pegawai akan semakin tinggi begitu juga sebaliknya.

Selain itu nilai koefisien regresi tertinggi pada variabel Fleksibilitas Kerja adalah indikator F2 yaitu fleksibilitas jadwal kerja sebesar 0,794. Hal ini mengindikasikan bahwa fleksibilitas jadwal kerja dapat lebih utama diterapkan di BSSN. Saat ini BSSN memiliki kebijakan flexitime 15 menit dan shift kerja khusus tatanan normal baru pasca pandemi covid-19, yaitu shift 1 (07.00 s.d. 15.00) dan shift 2 (10.00 s.d. 18.00). hal tersebut sudah baik, namun bisa lebih ditingkatkan lagi misalnya dengan menambah flexitime yang awalnya 15 menit menjadi 60 menit atau 90 menit.

Berdasarkan hasil perhitungan statistik pada pembuktian hipotesis, terlihat adanya pengaruh positif dan signifikan dari fleksibilitas kerja terhadap kinerja pegawai. Sehingga dapat disimpulkan bahwa teori mengenai fleksibilitas kerja dan kinerja pegawai sesuai dengan kondisi dan dapat diterapkan di BSSN. Pengaturan jam kerja fleksibel memberikan lebih banyak kebebasan kepada pegawai dalam mengatur jam kerja yang mereka inginkan. Bekerja dalam jam kerja fleksibel memungkinkan orang mengatur kehidupan sehari-hari mereka dengan lebih baik dan mengurangi konflik keluarga dan pekerjaan. Pegawai diijinkan untuk memilih jam berapa mereka bisa memulai dan menyelesaikan pekerjaan cenderung lebih puas dengan pekerjaan mereka. Pola fleksibilitas kerja ini perlahan akan mengubah pola lama ke pola yang baru, sehingga diharapkan produktivitas kerja dapat naik. Hal tersebut mengindikasikan bahwa terdapat pengaruh positif dari penerapan fleksibilitas kerja terhadap kinerja pegawai.

Hasil ini juga menunjukkan bahwa penelitian ini memiliki kebaruan dalam hal metode analisis, yaitu Structural Equation Model dan lokus yaitu pada Badan Siber dan Sandi Negara serta memperkuat hasil penelitian sebelumnya yang dilakukan oleh Nonik M dan M Ramadhan Slamet (2019) tentang Pengaruh Gaji, Jam Kerja Fleksibel dan Stres Kerja terhadap Kinerja Karyawan pada Perusahaan di Kota Batam, yang menggunakan analisis regresi linear berganda dengan hasil 
yang menunjukkan bahwa fleksibilitas kerja berpengaruh terhadap kinerja karyawan pada perusahaan di Kota Batam.

- Pengaruh Keseimbangan Kehidupan Kerja terhadap Kinerja Pegawai BSSN

Pendapat responden tentang pengaruh variabel keseimbangan kehidupan kerja terhadap kinerja pegawai adalah sebesar 3,981 > 1,96 (nilai Zkritis untuk derajat kepercayaan 95\%) dengan nilai probabilitas (p) sebesar 0,00 $<0,05$ dan nilai koefisien regresi pengaruh sebesar 0,221 (positif), sehingga dapat disimpulkan bahwa $\mathrm{H} 0$ diterima dan semakin tinggi keseimbangan kehidupan kerja maka kinerja pegawai akan semakin tinggi begitu juga sebaliknya.

Selain itu nilai koefisien regresi tertinggi pada variabel keseimbangan kehidupan kerja adalah indikator K3 yaitu Personal Life Enhancement of Work (sejauhmana kehidupan pribadi seseorang dapat meningkatkan performa individu dalam dunia kerja) sebesar 0,81. Hal ini mengindikasikan bahwa kehidupan pribadi yang meningkatkan performa kerja dapat lebih utama diterapkan di BSSN. Bentuknya bisa dilakukan dengan cara memberikan fasilitas kepada pegawai yang dapat mendukung kehidupan pribadi dan pekerjaan sekaligus yang belum diterapkan di BSSN sebelumnya, misalnya pengadaan jemputan gratis, mengadakan kegiatan rekreasi kantor dan lain lain.

Berdasarkan hasil perhitungan statistik pada pembuktian hipotesis, terlihat adanya pengaruh positif dan signifikan dari keseimbangan kehidupan kerja terhadap kinerja pegawai. Sehingga dapat disimpulkan bahwa teori mengenai keseimbangan kehidupan kerja dan kinerja pegawai sesuai dengan kondisi dan dapat diterapkan di BSSN. Keseimbangan kehidupan kerja merupakan kemampuan individu untuk memenuhi komitmen kerja dan keluarga, serta bertanggung jawab kepada aktivitas di luar pekerjaan lainnya. Adanya keseimbangan antara keterlibatan peran yang terjadi dalam kehidupan pegawai itu sendiri dimana pegawai dapat menikmati dalam kehidupan di lingkungan kerja maupun di luar pekerjaan seperti, rekreasi, berkumpul bersama teman maupun dengan keluarga. Hal tersebut akan berdampak baik bagi pegawai dimana dalam keseimbangan akan mempengaruhi kehidupan dari pegawai dalam suatu organisasi maupun perannya di luar organisasi. Ini mengindikasikan bahwa terdapat pengaruh positif dari penerapan keseimbangan kehidupan kerja terhadap kinerja pegawai.

Hasil ini juga menunjukkan bahwa penelitian ini mempunyai kebaruan dalam hal metode analisis yaitu Structural Equation Model dan lokus yaitu pada Badan Siber dan Sandi Negara. Selain itu, juga memperkuat hasil penelitian sebelumnya yang dilakukan oleh Saina, Riane Johnly Pio dan W. Rumawas (2016) tentang Pengaruh Worklife Balance dan Kompensasi terhadap Kinerja Karyawan pada PT PLN (Persero) Wilayah Suluttenggo Area Manado, yang menggunakan analisis regresi linear berganda yang menunjukkan hasil bahwa Worklife balance berpengaruh terhadap kinerja karyawan karena keselarasan antara kehidupan pribadi dan pekerjaan merupakan kebutuhan penting setiap karyawan yang dapat mempengaruhi suasana hati, fokus pikiran, dan tindakan dalam bekerja. Oleh karena itu, semakin tinggi kepuasan karyawan terhadap Worklife Balance semakin tinggi 
pula kualitas kinerja karyawan pada PT PLN (Persero) wilayah Suluttenggo Area Manado.

- Pengaruh Penghargaan terhadap Kinerja Pegawai BSSN

Pendapat responden tentang pengaruh variabel penghargaan terhadap kinerja pegawai adalah sebesar 4,5>1,96 (nilai Zkritis untuk derajat kepercayaan 95\%) dengan nilai probabilitas (p) sebesar $0,00<0,05$ dan nilai koefisien regresi pengaruh sebesar 0,16 (positif), sehingga dapat disimpulkan bahwa $\mathrm{H} 0$ diterima dan semakin tinggi lingkungan kerja non fisik penghargaan maka kinerja pegawai akan semakin tinggi begitu juga sebaliknya.

Selain itu nilai koefisien regresi tertinggi pada variabel penghargaan adalah indikator K2 yaitu ekstrinsik tidak langsung sebesar 0,783. Hal ini mengindikasikan bahwa penghargaan yang bersifat ekstrinsik tidak langsung dapat lebih utama diberikan oleh BSSN. Hal ini bisa dilakukan dengan cara memberikan kesempatan untuk peningkatan kompetensi seperti pelatihan, lalu pemberian promosi pada pegawai dengan kinerja terbaik dalam 2 tahun berturut-turut sesuai PP 30 Tahun 2019, dan penghargaan lainnya yang dapat mendorong kinerja pegawai.

Berdasarkan hasil perhitungan statistik pada pembuktian hipotesis, menunjukkan adanya pengaruh positif dan signifikan dari penghargaan terhadap kinerja pegawai. Sehingga dapat disimpulkan bahwa teori mengenai penghargaan dan kinerja pegawai sesuai dengan kondisi dan dapat diterapkan di BSSN. Penghargaan merupakan salah satu elemen yang dapat dimanfaatkan organisasi untuk memotivasi pegawai agar dapat memberikan kontribusi yang maksimal. Pemberian penghargaan tersebut merupakan upaya pemimpin dalam memberikan balas jasa atas hasil kerja pegawai, sehingga dapat mendorong bekerja lebih giat dan berpotensi. Hal tersebut mengindikasikan bahwa terdapat pengaruh positif dari pemberian penghargaan terhadap kinerja pegawai.

Hasil penelitian ini memiliki kebaruan dalam hal metode analisis yaitu Structural Equation Model dan lokus yaitu pada Badan Siber dan Sandi Negara, serta memperkuat hasil penelitian sebelumnya yang dilakukan oleh Aldila Saga Prabu dan Dewie Tri Wijayanti (2016) tentang Pengaruh Penghargaan dan Motivasi terhadap Kinerja Karyawan (Studi pada Divisi Penjualan PT. United Motors Center Suzuki Ahmad Yani, Surabaya), yang menggunakan analisis regresi linear berganda yang menunjukkan hasil bahwa penghargaan berpengaruh positif signifikan terhadap kinerja karyawan. Hal ini menunjukkan bahwa semakin tinggi pemberian penghargaan secara terus menerus terhadap karyawan, maka akan berdampak pada semakin meningkatnya kinerja karyawan pada Divisi Penjualan PT. United Motors Center Suzuki Ahmad Yani, Surabaya.

- Pengaruh Lingkungan Kerja Non Fisik terhadap Kinerja Pegawai BSSN

Pendapat responden tentang pengaruh variabel lingkungan kerja non fisik terhadap kinerja pegawai adalah sebesar 3,262 >1,96 (nilai Zkritis untuk derajat kepercayaan 95\%) dengan nilai probabilitas (p) sebesar 0,001 <0,05 dan nilai koefisien regresi pengaruh sebesar 0,16 (positif), sehingga dapat disimpulkan bahwa 
H0 diterima dan semakin tinggi lingkungan kerja non fisik maka kinerja pegawai akan semakin tinggi begitu juga sebaliknya.

Selain itu nilai koefisien regresi tertinggi pada variabel lingkungan kerja non fisik adalah indikator L3 yaitu hubungan antara atasan dengan bawahan sebesar 0,714. Hal ini mengindikasikan bahwa hubungan yang baik antara atasan dan bawahan dapat lebih utama diberikan di BSSN. Hal ini bisa dilakukan dengan cara penerapan atasan sebagai coach dan mentor yang dapat berlaku sebagai rekan kerja ataupun tempat konsultasi, selain itu diharapkan atasan dan bawahan dapat bekerja secara berkolaborasi.

Berdasarkan hasil perhitungan statistik pada pembuktian hipotesis, terlihat adanya pengaruh positif dan signifikan dari lingkungan kerja non fisik terhadap kinerja pegawai. Sehingga dapat disimpulkan bahwa teori mengenai lingkungan kerja non fisik dan kinerja pegawai sesuai dengan kondisi dan dapat diterapkan di BSSN. Lingkungan non fisik tidak bisa diabaikan begitu saja, karena lingkungan non fisik juga dapat mempengaruhi kinerja pegawai. Organisasi hendaknya dapat menciptakan hubungan yang baik antar para pegawai di organisasi, sehingga dapat mendukung satu sama lain untuk mencapai tujuan bersama. Hal tersebut mengindikasikan bahwa terdapat pengaruh positif dari pemberian lingkungan kerja non fisik terhadap kinerja pegawai.

Hasil penelitian ini memiliki kebaruan dalam hal metode analisis, yaitu Structural Equation Model dan lokus yaitu pada Badan Siber dan Sandi Negara serta memperkuat hasil penelitian sebelumnya yang dilakukan oleh Noerlestari dan Anita Silvianita (2013) tentang Pengaruh Lingkungan Kerja Non Fisik terhadap Kinerja Karyawan Telemarketing pada PT. Comment Indonesia (Homedirect) Jakarta, yang menggunakan analisis regresi linear dengan hasil yang menunjukkan bahwa penghargaan berpengaruh positif signifikan terhadap kinerja karyawan. Hal ini juga menunjukkan bahwa pengaruh lingkungan kerja non fisik terhadap kinerja karyawan adalah searah (positif), yang artinya bahwa peningkatan lingkungan kerja non fisik akan mengakibatkan peningkatan terhadap kinerja pegawai.

\section{SIMPULAN DAN SARAN}

Fleksibilitas kerja pegawai BSSN berpengaruh positif dan signifikan terhadap kinerja pegawai BSSN. Artinya, pengaturan jam kerja fleksibel memberikan lebih banyak kebebasan kepada pegawai dalam mengatur jam kerja yang mereka inginkan. Bekerja dalam jam kerja fleksibel memungkinkan orang mengatur kehidupan sehari-hari mereka dengan lebih baik dan mengurangi konflik keluarga dan pekerjaan.

Keseimbangan kehidupan kerja pegawai BSSN berpengaruh positif dan signifikan terhadap kinerja pegawai BSSN, yang berdasarkan implikasi teori dapat dijelaskan bahwa keseimbangan kehidupan kerja merupakan kemampuan individu untuk memenuhi komitmen kerja dan keluarga, serta bertanggung jawab kepada aktivitas di luar pekerjaan lainnya. Keseimbangan tersebut terjadi antara keterlibatan peran dalam kehidupan pegawai, dimana pegawai dapat menikmati kehidupan di lingkungan kerja maupun di luar pekerjaan, seperti rekreasi, berkumpul bersama teman maupun dengan keluarga. 
Penghargaan pegawai BSSN berpengaruh positif dan signifikan terhadap kinerja pegawai BSSN. Ini sesuai dengan landasan teori MSDM yaitu penghargaan merupakan salah satu elemen yang dapat dimanfaatkan organisasi untuk memotivasi pegawai agar dapat memberikan kontribusi yang maksimal. Pemberian penghargaan merupakan upaya pemimpin dalam memberikan balas jasa atas hasil kerja pegawai, sehingga dapat mendorong bekerja lebih giat dan berpotensi. Hal tersebut mengindikasikan bahwa terdapat pengaruh positif dari pemberian penghargaan terhadap kinerja pegawai.

Lingkungan Kerja Non Fisik di BSSN berpengaruh positif dan signifikan terhadap kinerja pegawai BSSN. Berdasarkan implikasi teori dapat dijelaskan bahwa lingkungan non fisik tidak bisa diabaikan begitu saja, karena lingkungan non fisik juga dapat mempengaruhi kinerja pegawai. Organisasi hendaknya dapat menciptakan hubungan yang baik antar para pegawai di organisasi, sehingga dapat mendukung satu sama lain untuk mencapai tujuan bersama. Hal tersebut mengindikasikan bahwa terdapat pengaruh positif dari pemberian lingkungan kerja non fisik terhadap kinerja pegawai.

Dari kesimpulan ini, maka saran yang dapat diberikan penulis adalah: pertama, terhadap variabel fleksibilitas kerja, Biro OSDM dapat menerapkan manajemen kinerja sesuai PP 30 Tahun 2019 tentang Manajemen Kinerja PNS, dengan salah satu tahapannya adalah perencanaan kinerja yaitu dengan membuat SKP (sasaran kinerja pegawai) dengan memperhatikan Renstra, Perjanjian Kinerja, OTK, Urjab dan SKP atasan langsung. Dengan menerapkan hal ini diharapkan akan mendapatkan output hasil yang jelas dan terukur. Sehingga jika hal ini sudah sesuai maka pelaksanaan pekerjaan dengan fleksibilitas jam kerja akan mudah diterapkan, karena kinerja tidak lagi dilihat dari proses, namun dilihat dari output dan outcome.

Selain itu penerapan fleksibilitas kerja di BSSN juga dapat ditingkatkan lagi, yang mulanya berupa flexitime selama 15 menit, menjadi lebih lama menjadi 90 menit, dan penerapan Work From Home (WFH) dapat terus diterapkan setelah pandemi covid-19 berakhir, tentunya dengan memperhatikan persyaratanpersyaratan tertentu. Dalam hal ini dibutuhkan pemantauan dan juga trust atau kepercayaan dari pimpinan kepada bawahan.

Kedua, dari variabel keseimbangan kehidupan kerja, Biro OSDM dapat membuat kebijakan terkait keseimbangan kehidupan kerja di lingkungan BSSN yang berisikan mengenai pegawai yang harus dapat membagi waktu dengan baik, antara pekerjaan, keluarga dan kehidupan pribadi, sehingga pegawai tidak dituntut untuk selalu bekerja di luar jam kantor. Bahkan diharapkan pegawai dapat mengambil cuti dalam setiap tahunnya. Dalam hal ini juga diharapkan seluruh atasan mendukung dan tidak ada lagi beban kerja setelah jam kantor, agar pegawai memiliki kehidupan keluarga dan pribadi yang baik, sehingga nantinya berpengaruh pada kinerja di kantor agar lebih maksimal. Selain itu juga harus diperhatikan fasilitas-fasilitas yang dapat diberikan kantor yang belum ada sebelumnya untuk mendukung pegawai seperti jemputan gratis, gathering pegawai dan juga daycare untuk penitipan anak agar pegawai dapat lebih berkonsentrasi dalam bekerja.

Ketiga, dari variabel penghargaan, Biro OSDM dapat menerapkan kebijakan mengenai penghargaan pegawai. Kebijakan ini berisikan mengenai pegawai dengan 
kriteria apa saja yang dapat diberikan penghargaan pegawai, mulai dari berdasarkan kinerja sesuai PP 30 Tahun 2019 dengan diberikannya promosi, atau prioritas pengembangan pegawai, lalu berdasarkan kedisiplinan dengan diterapkannya employee of the month tiap unit kerja, serta berdasarkan prestasi yang telah dilakukan oleh pegawai seperti memiliki ide dan inovasi yang dapat memajukan organisasi. Bentuk penghargaannya dapat ditetapkan bermacam-macam, tidak perlu berupa uang atau tanda penghargaan, namun dapat berupa prioritas pengembangan pegawai seperti pelatihan, seminar ke luar negeri dan lain lain. Selain itu, himbauan kepada para atasan agar dapat memberikan penghargaan intrinsik kepada bawahan dalam hal pencapaian kinerja agar bawahan merasa diapresiasi dan lebih semangat dalam bekerja, misalnya dengan ucapan terima kasih.

Keempat, dari variabel lingkungan kerja non fisik, Biro OSDM dapat mengusulkan kepada para atasan untuk bekerja secara partnership tanpa ada tekanan dan intimidasi, serta menerapkan sistem kerja tanpa kesenioritasan, karena saat ini masih banyak ditemukan sistem kesenioritasan dalam unit kerja yang membuat pegawai junior kurang berkembang. Hal ini bisa dilakukan dengan cara penerapan atasan sebagai coach dan mentor yang dapat berlaku sebagai rekan kerja ataupun tempat konsultasi, diharapkan atasan dan bawahan dapat bekerja secara berkolaborasi. Selain itu diadakan kegiatan-kegiatan yang dapat mempererat kekompakan pegawai dengan kegiatan bersama atau gathering pegawai. Serta diharapkan tidak ada lagi unit kerja yang ego sektoral dan diharapkan unit kerja saling berkolaborasi dan bekerja sama untuk kemajuan BSSN.

\section{DAFTAR PUSTAKA}

Armstrong, M., \& Murlis, H. (2007). Fundementals of Reward Management. In Reward Management: A Handbook of Remuneration Strategy and Practice.

Bangun, W. (2012). Manajemen Sumber Daya Manusia. Erlangga.

Carlson, D. S., Grzywacz, J. G., \& Michele Kacmar, K. (2010). The relationship of schedule flexibility and outcomes via the work $\square$ family interface. Journal of Managerial Psychology. https://doi.org/10.1108/02683941011035278

Dharma Setyawan Salam. (2004). Manajemen Pemerintahan Indonesia. In Politik dan pemerintahan Indonesia.

Fanda, N. M., \& Slamet, M. R. (2019). Pengaruh Gaji, Jam Kerja Fleksibel Dan Stres Kerja Terhadap Kinerja Karyawan Pada Perusahaan Di Kota Batam. Journal of Applied Managerial Accounting, 3(1), 81-95. https://doi.org/10.30871/jama.v3i1.965

Fisher, G. G., Bulger, C. A., \& Smith, C. S. (2009). Beyond Work and Family: A Measure of Work/Nonwork Interference and Enhancement. Journal of Occupational Health Psychology. https://doi.org/10.1037/a0016737 
Ghozali, I. (2017). Model Persamaan Struktural. Konsep dan Aplikasi Dengan Program AMOS 24.0. Update Bayesian SEM. In Model Persamaan Struktural. Konsep dan Aplikasi Dengan Program AMOS 24. Update Bayesian SEM. https://doi.org/10.1016/j.ando.2009.02.007

Karina Noerlestari, \& Silvianita, A. (2013). Pengaruh Lingkungan Kerja Non Fisik terhadap Kinerja Karyawan Telemarketing pada PT. Comment Indonesia (Homedirect) Jakarta. Journal of Chemical Information and Modeling, 53(9), 1689-1699. https://doi.org/10.1017/CBO9781107415324.004

Nawawi, H. H. (1997). Manajemen Sumber Daya Manusia. In Manajemen Sumber Daya Manusia.

Nitisemito, \& A. S. (2001). Manajemen Personalia. In Bogor: Ghalia Indonesia.

Norgate, S. H., \& Cooper, C. L. (2020). Designing our healthier future lives: Bridging science and policy for flexible work. In Flexible Work. https://doi.org/10.4324/9780429326585-2

Pandiangan, H. (2018). Flexible Working Arrangement dan Pengaruhnya terhadap Work-Life Balance pada Driver Layanan Jasa Transportasi Online di Kota Yogyakarta.

Parkes, L. P., \& Langford, P. H. (2008). Work-life balance or work-life alignment? Journal of Management \& Organization.

Prabu, A. S., \& Wijayanti, D. T. (2016). Pengaruh Penghargaan dan Motivasi Terhadap Kinerja Karyawan (Studi Pada Divisi Penjualan PT. United Motors Center Suzuki Ahmad Yani, Surabaya). Jurnal Ekonomi Bisnis Dan Kewirausahaan, 5(2), 104. https://doi.org/10.26418/jebik.v5i2.17144

Rivai, V. (2013). Manajemen Sumber Daya Manusia. Manajemen Sumber Daya Manusia Untuk Perusahaan Dari Teori Ke Praktik.

Solimun, Fernandes, A. A. R., \& Nurjannah. (2017). Metode Statistika Multivariat Pemodelan Persamaan Struktural (SEM) Pendekatan WarpPLS. In Metode Statistika Multivariat Pemodelan Persamaan Struktural (SEM) Pendekatan WarpPLS.

Suwatno, H. \& P. D. . (2011). Manajemen SDM Dalam Organisasi Publik \& Bisnis. In Manajemen. 